\title{
An Interactive Teaching Mode Based on Educational Games - Case Study of Acupuncture Course
}

\author{
https://doi.org/10.3991/ijet.v14i17.11205 \\ Qiong Pan \\ Yun Nan Xin Xing Occupations Institute, Qujing, China \\ panqiong 8866@163.com
}

\begin{abstract}
As people pay more and more attention to the major of traditional Chinese medicine (TCM), social demand for TCM talents also becomes larger and larger. But, the content of TCM acupuncture major is abstract, with high practical operation. Traditional acupuncture course is taught with "cramming method" so that students cannot understand and grasp the concrete knowledge of this major. This may even have negative impacts on some students. The interactions between the teacher and students are few, and students passively absorb teaching content. The positive feedbacks of teaching cannot be gained, either, thus affecting the teaching effect to certain degree. On this basis, an interactive teaching mode based on educational games was proposed in this study, and such interactive teaching mode based on educational games was applied in the courses of acupuncture major. Firstly, the current situations and features of educational games and interactive education mode were analyzed. Besides, acupuncture major was taken for example to introduce a series of teaching module development processes of educational games for resource module collation, project courseware management, target test questions, task allocation, courseware making and one-key release of acupuncture courses. It is found through the survey that, students more accept such interactive teaching mode based on educational games, and their learning efficiency improves. Such teaching method is obviously superior to traditional teaching methods.
\end{abstract}

Keywords-Educational game; online collaborative courseware development system; interactive teaching mode; acupuncture major

\section{Introduction}

As a required course of TCM major and rehabilitation therapy major in China, acupuncture is one of important fields for medical colleges to learn and study, and receives more and more attention [1]. Besides, the grasp of acupuncture concerns the inheritance of ancient medical skills. Due to many course contents and large coverage of professional knowledge, students need to integrate multidisciplinary knowledge and achieve the span from theory to practice, so students have certain understanding and operation difficulties. It is urgent and especially important to let students combine theory and practice, really master the operation skills of acupuncture for the purpose 
of application, give play to the characteristic advantages of acupuncture and cultivate TCM talents [2]. At present, classroom teaching is still a general method for acupuncture teaching. The traditional cramming teaching is adverse to mobilizing students' learning enthusiasm and stimulating their learning interest. Students generally express such problems as the abstract and scattered knowledge of acupuncture, difficulty in remembering and few practical operations. Now, understanding and operation of acupuncture needle are discussed as below.

With rapid development of information technology, the service functions which emerge with internet development and application become more and more diversified [3]. The teaching mode of educational games develops rapidly under such background. With internet technology, educational games make the education process "game-based", and make boring and difficult knowledge simplified. Students can maximize learning efficiency in the relaxing atmosphere. Meanwhile, as people's cognition of current teaching mode innovates, interactive teaching mode is mostly accepted by most people. Through the interactive teaching mode, students no longer passively accept the individuals of knowledge. They actively participate in classroom interactions so that students more deeply grasp the course.

Thus, the students of acupuncture major were chosen as the objects of study, and interactive teaching mode of educational games was used for teaching practice. It was effective combined with an online collaborative courseware development system to keep motivating students' learning motivation in the practical process and adjust the teaching mode flexibly according to students' experience and response so as to provide a new perspective for acupuncture teaching, provide the reference for traditional medical teaching mode, and cultivate more qualified TCM talents for the society.

\section{State of the Art}

The educational game is an "education-based game", and it combines educational preciseness and interestingness of games. Nowadays, it receives more and more attention at home and abroad. Foreign research on educational games started from video game. Marchiori et al. [4] studied the fast iteration of integration of education \& teaching mode and video game with computer technology. From educational games to computer games, the types of relevant game software also increase. Microsoft and Massachusetts Institute of Technology cooperated in the project of Games to Teach [5]. The research history of China for educational games is not long, and there is still certain gap with foreign countries. Although there are just a few relevant researches, the research achievements are rich. In particular, many attempts have been made in the aspect of integrating middle and primary school classroom and educational games. Tian et al. also proposed the research and design on educational games for school children based on Mobile augmented reality. This research improved the design and development of educational games from a new perspective and strategy, and gained the approval [6]. Pu also proposed to explore the integration of educational games and primary school mathematics, analyzed the importance and put forward some integra- 
tion ways [7]. Nowadays, educational games have received more and more good reputations in China, and are highly evaluated.

The diversified interactive teaching regards promoting innovation spirit and practical ability as the core, and aims to drive the all-round development of students. The interactive teaching has many advantages in practice, so many domestic and overseas lay the emphasis on the application of multiple interactions in teaching. Olasina [8] proposed symbolic interaction theory. Kang \& Cheng [9] studied the teacher's classroom language and established the causal relationship between teaching and learning. Domestic researches on interactive learning are also abundant. Gu [10] carried out the empirical study on the basis of input theory and Interactive hypothesis. Shan applied interactive teaching in college English and provided the reference for college English education reform [11]. On the whole, diversified interactive teaching involves an increasing wide scope in the educational field, which is not just reflected in the class of middle and primary schools, but also embodied in college quality education and formative education of children. This manifests its important position and the broad development prospect.

TCM as the essence of Chinese ancient medical culture is a field with the strongest capability of independent innovation in life sciences. However, inheritance crisis appears to TCM, and the advantages and characteristics are not obvious. Even the service objects and field shrink. From the perspective of professional TCM teaching, the following defects exist in the teaching process: the freshmen lack the foundation of TCM study, and TCM is abstract. The "creaming" teaching lacking interaction cannot well make students have a deep understanding; the dull and boring theoretical knowledge cannot motivate students' subjective initiative, and most students learn in order to deal with the examinations; the teaching mode is mostly PPT presentation, and there are no cooperation and exchange opportunities between students and the teacher, thus leading to the poor learning efficiency. Based on the above defects, the interactive teaching mode of acupuncture courses based on educational games was proposed in this study. This mode is mainly oriented to the students of acupuncture major. For students and the teacher, they can maximize learning efficiency and really apply what they have learned. The innovations are as below: firstly, the mode adopts the method of educational games and expand the boring TCM theory in the form of games to motivate students' subjective initiative so that they can experience extensive and profound TCM in the relaxing and pleasant atmosphere. Secondly, this mode combines interactive teaching mode, promotes the interaction and exchange between students and the teacher and among students and experiences the abstract theory of TCM with cases, conclusion and practice teaching methods so that students have the better understanding of TCM. A new online courseware Collaborative development system was applied in this study so that traditional classroom teaching is no longer performed in the form of PPT or video recording, but pays more attention to mobilizing students' feedbacks and thinking after class and achieving total involvement of courseware content in the design development and review process. It is hoped that this study can offer the reference for acupuncture teaching. 


\section{Interactive Teaching Mode Based on Educational Games}

\subsection{Teaching methodology of educational games}

Teaching methodology of educational games generally refers to the combination of educational method and games as the auxiliary tool in the teaching process to teach students knowledge and skills. The games mainly involve some simulated trainings and relevant professional skills [14]. In the game-based atmosphere, the training objective and learners' psychological features are designed, and the proper learning strategy and evaluation method are chosen. Besides, it can enhance interestingness and initiative of students in the learning process, help learners analyze the specific teaching purpose and train their logic and calculation thinking. Students can experience and learn relevant classroom knowledge so that the learning process becomes relaxing and efficient. The design of teaching method based on educational games should follow the principle of proper difficulty, the principle of simple and concise teaching and game rules, immediate feedback principle, strong target principle and principle of offering help. The whole teaching design framework is mainly divided into six links, as shown in Fig.1. The six links are analyzed as below.

The learning objective concretely and explicitly expresses the visible behaviors that learners should show after learning, also called objective. For different learning contents, the learning objectives differ. The setting of learning objectives concerns the setting of game objectives. The learning objective refers to a final status that learners should reach. So, the learning objectives should be confirmed first before setting the objective of educational game development.

The learners' analysis should embody their dominant role in the design process of educational games. In other words, a reasonable teaching design scheme with application value should be designed according to learners' knowledge reserve, cognitive development and learning motivation.

The game task design is the core the whole game design, and decides whether the learning content can be reconstructed through the game. The design mainly focuses on simulation of real learning task, is based on the specific questions and matched with learners' knowledge reserve and learning ability so as to play the positive motivation and teaching role.

The design of game situation aims to find out the game theme which conforms to teaching content through setting rules and applying concise and practical interface so that learners can enhance their concentration, utilize the cognitive tool and earning resources to fully inquire learning environment, test the knowledge they have learned and give feedbacks. 


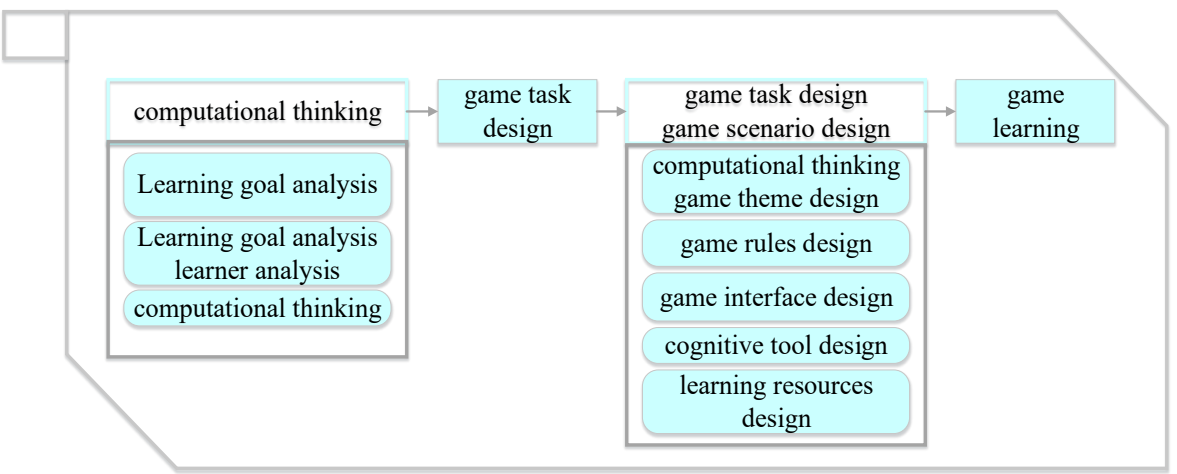

Fig. 1. Design framework of educational games

\subsection{Classroom Interactive teaching mode}

Interactive teaching is an educational pattern which combines "interaction" and "teaching", and regards teaching as a process of teaching and learning unification with dynamic development. It means in the teaching process, the teacher and students share their ideas and knowledge through mutual communication, dialogue and cooperation [15].

In the design process of interactive teaching, it is required to pay attention to classroom teaching diversification, guide students to participate in literature reading and cultivate students' ability to solve practical problems and innovate. Meanwhile, learning mode diversification should be noticed: students can be instructed via network platform, WeChat group and high-quality curriculum website in class and after class.

Evaluation method diversification should be paid attention to: students' performance in the group and periodical learning investigation can be integrated to train students' independent learning ability. Interactive teaching can really measure whether a lesson works. It not merely measures knowledge mastery, ability promotion and value changes, but also observes whether the actual teaching is student-centered. Under the guidance of the teacher, the joyful interactive process of both parties is stimulated.

The interactive teaching can stimulate students' learning interest, and contribute to students to digest classroom knowledge, to change the previous status of passive listening, to give play to learning initiative and to comprehend the knowledge through thinking. (Fig.2) 


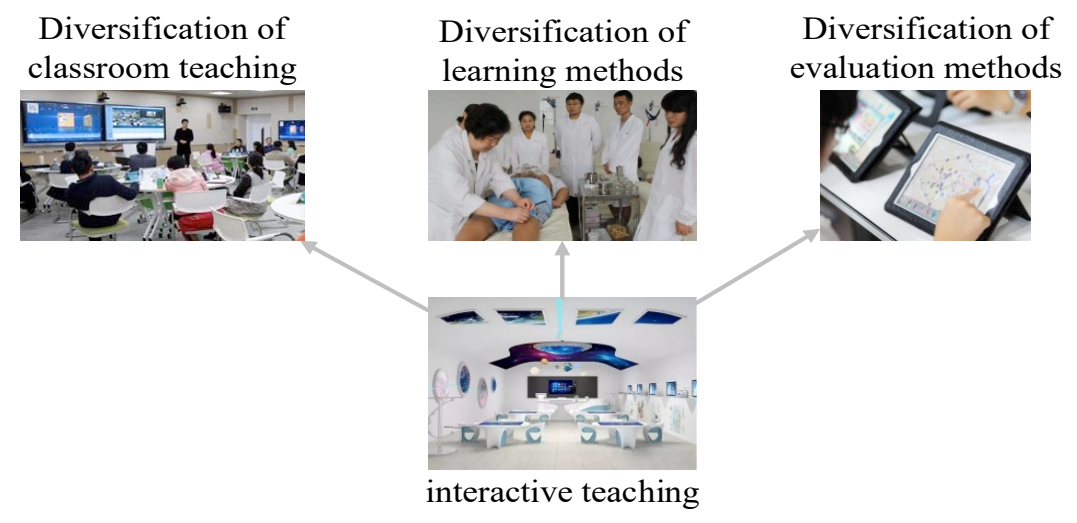

Fig. 2. Diversification module of interactive teaching

\subsection{Integration of educational games in interactive teaching mode}

The interactive teaching mode based on educational games motivates students' learning interest and thirst for knowledge and practice through educational games and interactive teaching mode so that students can better understand relevant professional terms and course contents. The elements of educational game development and the structural relationship are shown in Fig.3. The educational games are oriented to the teaching content of professional courses, and the teaching content is transformed into one or several questions and integrated in the game tasks so that the professional content and game figures can be effectively integrated.

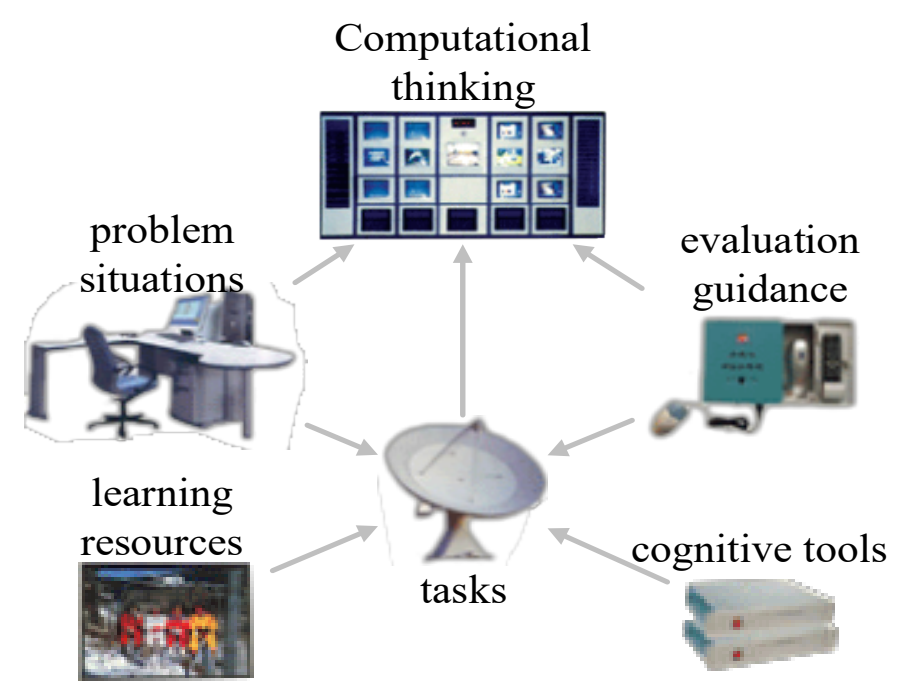

Fig. 3. Elements and structural relationship of educational game development 
The interactive teaching framework applied in this study is shown in Fig.6. The educational game mode is introduced in the interactive education mode. It can be seen from the figure that, there are mainly three sources of interactive mode formation: firstly, from the real classroom scene; secondly, from students' active learning; thirdly, some practical objectives with strong operability are designed with the task-driven method through creating the real learning situation so that students can actively practice, construct and improve their learning systems.

\begin{tabular}{|c|c|c|c|c|c|c|c|c|c|}
\hline flow & \multicolumn{2}{|c|}{ Before the class } & & \multicolumn{2}{|c|}{ in the class } & \multicolumn{3}{|c|}{ after the class } & \\
\hline flow & $\begin{array}{l}\text { autonomous } \\
\text { learning }\end{array}$ & testing & \multicolumn{2}{|c|}{$\begin{array}{c}\text { testing } \\
\text { knowledge development }\end{array}$} & $\begin{array}{l}\text { knowledge } \\
\text { feedback }\end{array}$ & \multicolumn{2}{|c|}{$\begin{array}{l}\text { knowledge } \\
\text { summary }\end{array}$} & & oud solutions \\
\hline teachers & $\begin{array}{l}\text { learning task } \\
\text { videos }\end{array}$ & $\begin{array}{l}\text { providing test } \\
\text { exercises }\end{array}$ & \multicolumn{2}{|c|}{$\begin{array}{l}\text { providing test exercises } \\
\text { exchanges and guidance }\end{array}$} & solutions & \multicolumn{2}{|c|}{$\begin{array}{l}\text { expansion and } \\
\text { promotion }\end{array}$} & $\underset{r}{\operatorname{provid}}$ & $\begin{array}{l}\text { iding electronic } \\
\text { resources }\end{array}$ \\
\hline $\begin{array}{c}\text { smart } \\
\text { classroom }\end{array}$ & \multicolumn{9}{|c|}{$\begin{array}{l}\text { presenting learning situations/providing resource platforms/interactive learning/presenting evaluation } \\
\text { information }\end{array}$} \\
\hline students & $\begin{array}{l}\text { Task-based } \\
\text { learning }\end{array}$ & $\begin{array}{l}\text { accepting } \\
\text { testing }\end{array}$ & $\begin{array}{l}\text { cooperative } \\
\text { learning }\end{array}$ & $\begin{array}{l}\text { accepting } \\
\text { testing }\end{array}$ & $\begin{array}{r}\text { summ } \\
\text { refl }\end{array}$ & $\begin{array}{l}\text { larizing } \\
\text { ection }\end{array}$ & & $\begin{array}{l}\text { nmarizi } \\
\text { eaning c }\end{array}$ & $\begin{array}{l}\text { zing reflection } \\
\text { construction }\end{array}$ \\
\hline
\end{tabular}

Fig. 4. Interactive teaching mode framework based on educational games

The process chart of online courseware collaborative development system is adopted in this study. The system supports SCROM standards, and is developed with Java Web technology. Users cooperate with each other through the system platform to achieve the whole process of courseware from teaching design, question bank, content edition, preview, review and release, and the courseware package with SCORM standards will be generated in the end. It breaks through the limitation that the standalone version of courseware cannot be shared and exchanged, and provides a strong platform where multi-users can edit, preview, audit, integrate and publish online at the same time. Hence, the sharing between the teacher and students and among students becomes possible.

\subsection{Effect evaluation of interactive teaching mode based on educational games}

The questionnaire survey method was used. The questionnaire was prepared by combining current evaluation indicator system. The questionnaires were mainly distributed in the form of electronic version and paper version. According to the interview opinions of relevant experts, the effect evaluation indicators of interactive teaching mode based on educational games involve five parts: game design, education nature, game nature, technology and artistry. Content design and scene design are mainly considered in the game design. The teaching objective, teaching content and learning result are mainly considered in education nature. The game nature mainly takes into account of situation setting and game experience. The operation level, operation status and design effect are mainly considered in technology. Interface design and media effect are mainly considered in artistry. AHP model is used for AHP analysis of the questionnaire. The formulas are as below. The indicator weights of each part are shown in Table 1. 


$$
\begin{gathered}
\frac{1}{\mathrm{~m}_{\mathrm{i}=1}} \sum_{\sum_{i}}^{\mathrm{m}}\left(\mathrm{y}_{i}-\hat{y}_{i}\right)^{2} \\
\frac{1}{\mathrm{~m}} \sum_{\mathrm{i}=1}^{\mathrm{m}}\left|\left(\mathrm{y}_{\mathrm{i}}-\hat{\mathrm{y}}_{\mathrm{i}}\right)\right| \\
\mathrm{R}^{2}=1-\frac{\mathrm{SS}_{\text {resdual }}}{\mathrm{SS}_{\text {total }}} \\
\mathrm{R}^{2}=1-\frac{\sum_{\mathrm{i}}\left(\hat{y}_{i}-y_{i}\right)^{2}}{\sum_{i}\left(\hat{y}_{i}-y_{i}\right)^{2}} \\
\mathrm{R}^{2}=1-\frac{\left(\sum_{\mathrm{i}}\left(\hat{y}_{i}-y_{i}\right)^{2}\right) / m}{\left(\sum_{i}\left(\hat{y}_{i}-y_{i}\right)^{2}\right) / m}
\end{gathered}
$$

\begin{tabular}{|c|c|c|c|}
\hline Indicator factor & Indicator weight & Alternative scheme & Indicator weight \\
\hline \multirow{2}{*}{1 Game design } & \multirow{2}{*}{0.2622} & 1.1 Content design & 0.1311 \\
\hline & & 1.2 Environment design & 0.1311 \\
\hline \multirow{3}{*}{2 Education nature } & \multirow{3}{*}{0.2751} & 2.1 Teaching objective & 0.0917 \\
\hline & & 2.2 Teaching content & 0.0917 \\
\hline & & 2.3 Learning result & 0.0917 \\
\hline \multirow{2}{*}{3 Game nature } & \multirow{2}{*}{0.2124} & 3.1 Situation setting & 0.1062 \\
\hline & & 3.2 Game experience & 0.1062 \\
\hline \multirow{3}{*}{4 Technology } & \multirow{3}{*}{0.1284} & 4.1 Operation level & 0.0428 \\
\hline & & 4.2 Operation status & 0.0428 \\
\hline & & 4.3 Design effect & 0.0428 \\
\hline \multirow{2}{*}{5 Artistry } & \multirow{2}{*}{0.1218} & 5.1 Interface design & 0.0609 \\
\hline & & 5.2 Medial effect & 0.0609 \\
\hline
\end{tabular}

Table 1. First-level and second-level indicator weights of educational games

According to the above table, the influence of game design and education nature on educational game evaluation is basically same, accounting for over $50 \%$ of the whole evaluation indicators. The influence of game nature is slightly weaker than that of education nature and game design, accounting for about $20 \%$. The influence of technology and artistry on educational game evaluation is basically same.

To further detail the evaluation system, the above second-level indicators were detailed into third-level indicators, and the questionnaire was prepared for the third-level indicator factors. The questionnaire data were analyzed. The importance frequency statistics of evaluation factors of third-level indicators in educational games is shown in Table 2. 
Table 2. Importance frequency statistics of evaluation factors $(\%)$

\begin{tabular}{|c|c|c|c|c|c|c|}
\hline $\begin{array}{l}\text { First-level } \\
\text { indicator }\end{array}$ & Factor & \begin{tabular}{|c} 
Very \\
important \\
\end{tabular} & Important & Indifferent & \begin{tabular}{c|} 
Non- \\
important
\end{tabular} & $\begin{array}{l}\text { Totally un- } \\
\text { important }\end{array}$ \\
\hline \multirow{6}{*}{ Game design } & A1 Objective design & 77.8 & 14.8 & 3.7 & 3.7 & \\
\hline & $\begin{array}{l}\text { A2 Content organiza- } \\
\text { tion }\end{array}$ & 44.4 & 55.6 & & & \\
\hline & A3 Game practice & 33.3 & 55.6 & 7.4 & 3.7 & \\
\hline & A4 Game interaction & 48.1 & 44.4 & 7.4 & & \\
\hline & A5 Game feedback & 44.4 & 30.7 & 18.5 & & \\
\hline & A6 Game evaluation & 37.0 & 40.7 & 22.2 & & \\
\hline \multirow{9}{*}{ Education nature } & $\begin{array}{l}\text { B1 Objective scienti- } \\
\text { ficity }\end{array}$ & 55.6 & 33.3 & 11.1 & & \\
\hline & $\begin{array}{l}\text { B2 Objective adapta- } \\
\text { tion }\end{array}$ & 59.3 & 29.6 & 3.7 & 7.4 & \\
\hline & $\begin{array}{l}\text { B3 Teaching adapta- } \\
\text { tion }\end{array}$ & 51,9 & 33.3 & 11.1 & & 3.7 \\
\hline & B4 Cognitive rules & 44.4 & 48.1 & 7.4 & & \\
\hline & $\begin{array}{l}\text { B5 Scientific ad- } \\
\text { vancement }\end{array}$ & 22.2 & 40.2 & 25.9 & 7.4 & 3.7 \\
\hline & $\begin{array}{l}\text { B6 Ideological correct- } \\
\text { ness }\end{array}$ & 25.9 & 74.1 & 22.1 & 11.1 & \\
\hline & $\begin{array}{l}\text { B7 Knowledge learn- } \\
\text { ing }\end{array}$ & 37.0 & 51.9 & 11.1 & & \\
\hline & B8 Ability training & 40.7 & 48.1 & 11.1 & & \\
\hline & $\begin{array}{l}\text { B9 Emotional experi- } \\
\text { ence }\end{array}$ & 51.6 & 40.7 & 7.4 & & \\
\hline \multirow{7}{*}{ Game nature } & $\begin{array}{l}\text { C1 Incentive mecha- } \\
\text { nism }\end{array}$ & 63.0 & 19.6 & 7.4 & & \\
\hline & C2 Problem solving & 40.7 & 51.9 & 7.4 & & \\
\hline & $\begin{array}{l}\text { C3 Exploration and } \\
\text { discovery }\end{array}$ & 55.6 & 40.7 & & 3.7 & \\
\hline & C4 Sense of immersion & 40.7 & 44.4 & 14.8 & & \\
\hline & $\begin{array}{l}\text { C5 Sense of satisfac- } \\
\text { tion }\end{array}$ & 48.1 & 40.7 & 7.4 & 3.7 & \\
\hline & C6 Sense of joy & 37.0 & 51.9 & 11.1 & & \\
\hline & $\begin{array}{l}\text { C7 Repetition and } \\
\text { playability }\end{array}$ & 51.9 & 22.2 & 22.2 & 3.7 & \\
\hline \multirow{6}{*}{ Technology } & D1 User guidance & 40.7 & 44.4 & 11.1 & 3.7 & \\
\hline & $\begin{array}{l}\text { D2 Operation practica- } \\
\text { bility }\end{array}$ & 55.6 & 40.7 & 3.7 & & \\
\hline & $\begin{array}{l}\text { D3 Software perfor- } \\
\text { mance }\end{array}$ & 37.0 & 55.6 & 7.4 & & \\
\hline & D4 Software operation & 33.3 & 66.7 & & & \\
\hline & D5 Operation status & 25.9 & 66.7 & 7.4 & & \\
\hline & D6 Operation level & 37.0 & 56.0 & 7.4 & & \\
\hline \multirow[t]{4}{*}{ Artistry } & E1 Medial application & 29.6 & 48.0 & 22.2 & & \\
\hline & E2 Interface effect & 55.6 & 44.4 & & & \\
\hline & E3 Medial selection & 51.9 & 48.1 & & & \\
\hline & E4 Medial design & 63.0 & 37.0 & & & \\
\hline
\end{tabular}

It can be seen from the above table that, the opinions basically focus on the columns of very important and important, and the percentages of the first two items concentrate between $62.4 \%$ and $100 \%$. Besides, a few people select unimportant or very 
unimportant. So, representativeness and applicability of third-level indicator system are strong.

\section{$4 \quad$ Teaching Example and Effect}

\subsection{Teaching example}

In the design of the whole teaching experiment operation module, software design of educational games and online courseware collaborative development system were mainly used. The function model of educational games is shown in Fig.5. The whole acupuncture teaching process mainly includes students and the teacher. Seeing from the demand analysis, students select game tasks and discover the problems in acupuncture therapy in such environment, and solve these problems with computing thinking. Finally, the whole process is evaluated. The teacher needs to present the acupuncture learning resources in the whole process, give feedbacks to students' questions and promote their study. The overall design structure of educational games includes demand analysis of educational games in the function model. In the design module, the game is decomposed into game function module and game support module. After entering the game function module, students firstly log in the game, enter the game activity, complete corresponding acupuncture task games and end the game. Some game-aided modules are also provided in the game process, including game description, prompt and help, etc. Relevant acupuncture teaching content resources are embodied in the game resource module. After completing the corresponding game module, students can enter the module to consolidate and review acupuncture-related knowledge. The game feedback module mainly covers integral award of the system, feedback and communication with the teacher and students after passing the game.

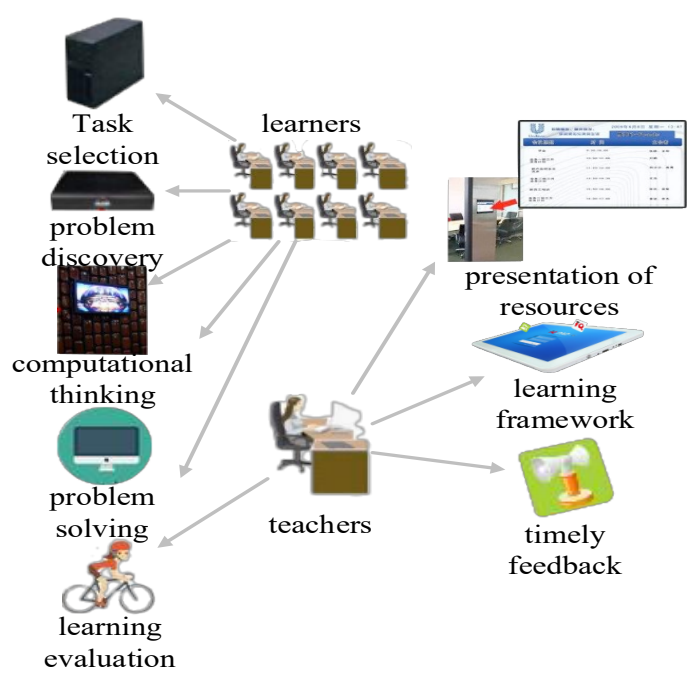

Fig. 5. Function module of educational games 


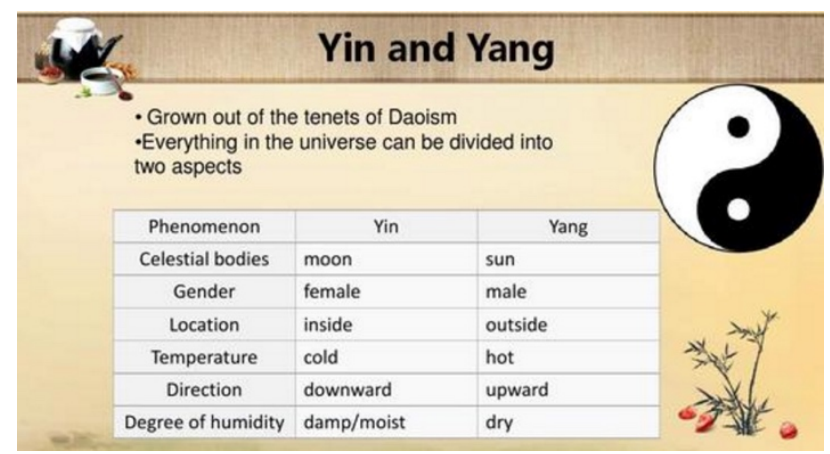

Fig. 6. Software screenshot I of educational game

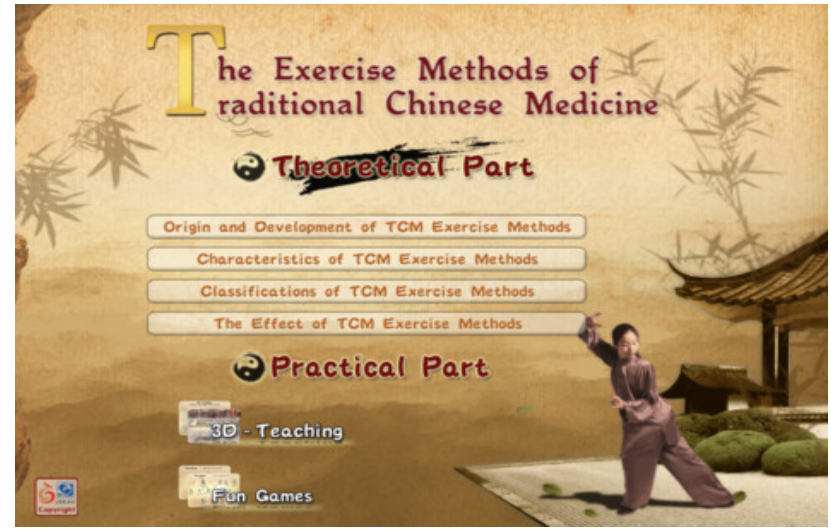

Fig. 7. Software screenshot II of educational game

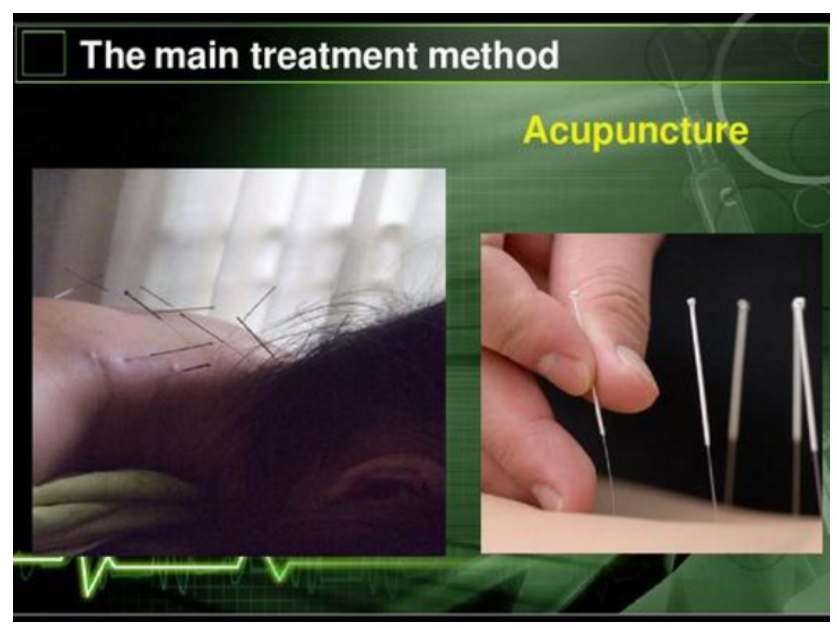

Fig. 8. Software screenshot III of educational game 


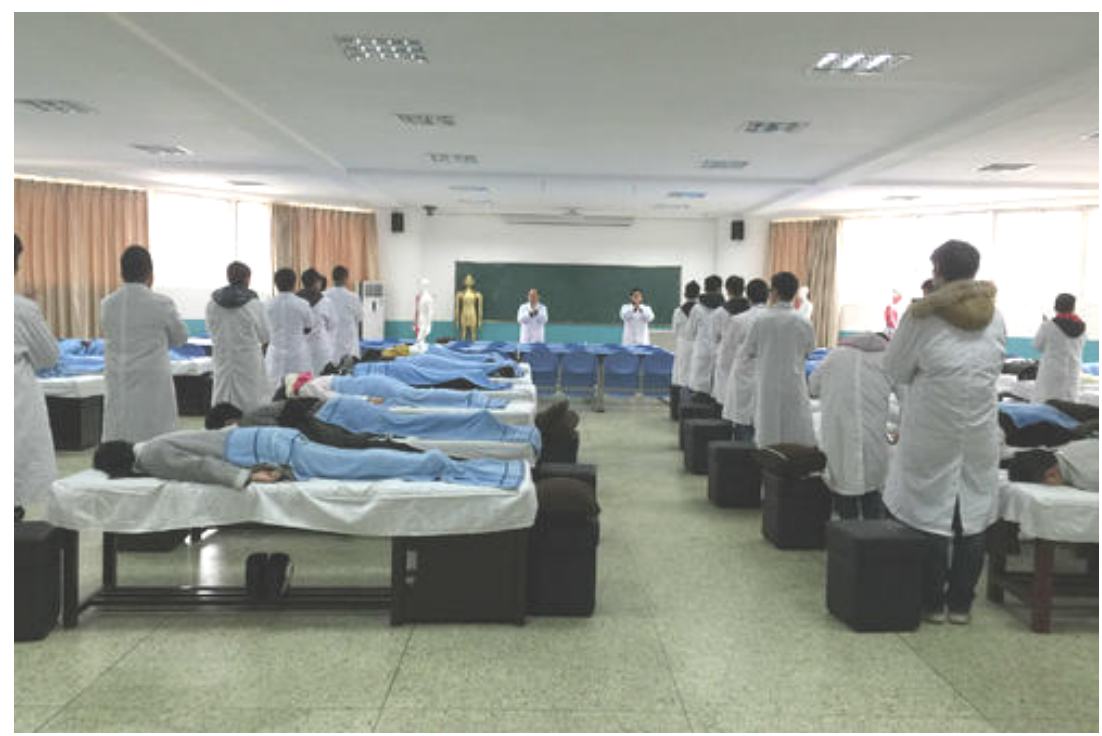

Fig. 9. Field exhibition link of educational game

Figs.6-9 show the teaching examples of application of interactive education mode based on educational games in acupuncture courses. In the teaching experiment process of educational games, corresponding learning module needs to be designed for the students to learn corresponding professional courses. Students firstly log in the game, read the relevant operation instructions of the educational game, and click "start" to enter the game situation. During solving the tasks in the game, computational thinking needs to be applied to solve acupuncture games. If the current level is passed, students will enter the next level. If they fail, they may try again until they pass the level. In this process, students can quit the game.

In the teaching experiment process, online courseware collaborative development system mainly covers resource template collation, project courseware management, target test questions, task allocation, courseware making, review modification and one-key release modules. The teacher puts the objectives of acupuncture-related content courseware into the target test question module, and allocates the permissions such as courseware modification and edit to students through task allocation module. Students mutually discuss and exchange based on their own understanding for courseware-related acupuncture teaching content, modify and edit the courseware according to their own understanding, and upload it to the resource template management module. The teacher checks, reviews and modifies the information fed back by students. Finally, the common teaching results of the teacher and students are released by the one-key release module. This process reflects the interactive teaching mode proposed in this study. The courseware making is no longer the unilateral teaching material of the teacher. Through communication and exchange with students, the teacher should guide them modify and edit the courseware so that they can have a deeper understanding of professional acupuncture knowledge. 


\subsection{Teaching effect}

In this study, the combination of educational games and interactive teaching mode was applied in acupuncture course teaching reform. Students' subjective initiative and learning enthusiasm can be motivated by educational games and interactive teaching mode so that they could have a more precision and deeper understanding of the course. The effect of the whole experiment process is shown in Fig.7. To test the teaching effect of the whole virtual teaching system, two classes of TCM major were chosen as the experimental group (62 students) and control group (53 students). The author made satiates of learning attitudes and learning motivations of both groups under such mode through the questionnaire from September 2018 to March 2019. The results are shown in Table 3 and Table 4.

Table 3. Comparison of mean score of learning attitude and score of each dimension in both groups

\begin{tabular}{|l|c|c|c|c|c|}
\hline \multicolumn{1}{|c|}{ Group } & Mean score & $\begin{array}{c}\text { Learning } \\
\text { interest }\end{array}$ & $\begin{array}{c}\text { Learning } \\
\text { experience }\end{array}$ & $\begin{array}{c}\text { Personal } \\
\text { learning habit }\end{array}$ & $\begin{array}{c}\text { Cognition of acupunc- } \\
\text { ture major }\end{array}$ \\
\hline $\begin{array}{l}\text { Experimental group } \\
(\mathrm{n}=62)\end{array}$ & $3.25 \pm 0.57$ & $3.28 \pm 0.82$ & $3.75 \pm 0.84$ & $3.34 \pm 0.82$ & $2.40 \pm 0.95$ \\
\hline Control group $(\mathrm{n}=53)$ & $3.15 \pm 0.85$ & $3.15 \pm 0.96$ & $3.51 \pm 0.92$ & $3.35 \pm 0.86$ & $2.62 \pm 1.09$ \\
\hline
\end{tabular}

Table 4. Comparison of learning motivation scores of both groups $(\bar{x} \pm s)$

\begin{tabular}{|l|c|c|c|c|c|c|}
\hline \multirow{2}{*}{ Group } & \multicolumn{3}{|c|}{ Internal motivation } & \multicolumn{3}{c|}{ External motivation } \\
\cline { 2 - 7 } & Total score & $\begin{array}{c}\text { Thirst for } \\
\text { knowledge }\end{array}$ & $\begin{array}{l}\text { Ability pur- } \\
\text { suit }\end{array}$ & Total score & $\begin{array}{c}\text { Reputation } \\
\text { acquisition }\end{array}$ & $\begin{array}{c}\text { Altruism } \\
\text { tendency }\end{array}$ \\
\hline $\begin{array}{l}\text { Experimental } \\
\text { group(n=62) }\end{array}$ & $65.27 \pm 14.12$ & $35.36 \pm 10.3$ & $27.86 \pm 6.03$ & $48.16 \pm 9.57$ & $21.71 \pm 5.67$ & $27.24 \pm 5.62$ \\
\hline $\begin{array}{l}\text { Control } \\
\text { group }(\mathrm{n}=53)\end{array}$ & $62.21 \pm 14.79$ & $36.29 \pm 7.83$ & $27.45 \pm 5.19$ & $49.06 \pm 10.2$ & $21.45 \pm 5.3$ & $26.19 \pm 5.12$ \\
\hline
\end{tabular}

It can be seen from Table 3 that, the difference in the learning experience of both groups is most obvious, followed by learning interest. Thus, the teaching mode proposed by this study is beneficial to improve the ability quality of acupuncture majors and academic results, and contributes to changing students' learning attitude. But, the difference in learning habit is small, and there is almost no statistical significance. Therefore, the teacher should combine other teaching modes on the basis of the teaching mode in this study.

Based on Table 4, the difference in the internal motivation is most obvious. The third for knowledge and ability pursuit differ greatly. The teaching mode proposed in this study contributes to motivating students' subjective initiative. They are willing to participate in interactions and actively explore, which is beneficial for acupuncture learning. 


\section{Conclusion}

Educational games and interactive teaching mode were combined in this study. First of all, the development status of both was analyzed. Then, the features of both were combined, and the patent - Online Collaborative Courseware Development System was used to form acupuncture course teaching based on educational games and interactive teaching mode. Meanwhile, the educational games, interactive teaching mode and the development process of computer-assisted instruction were introduced. The questionnaire survey was employed to evaluate the teaching effect, and SPSS was used for statistics. Finally, the following conclusions were gained:

- The acupuncture major teaching based on educational games and interactive teaching mode can display the boring knowledge learning through the relaxing games to improve students' learning interest and experience.

- The acupuncture major teaching was discussed through interactive teaching mode to improve students' subjective initiative and professional quality.

- The patent - Online Collaborative Courseware Development System was combined to expand the interactive mode by internet in the form of courseware making by both the teacher and students. In this way, students can really participate in the course design so that the course can be more reasonable, and students' understanding can be deeper.

- However, the teaching mode proposed in this study still has certain defects. Based on the above analysis, students' habits improve little under such mode. Hence, more diversified teaching modes should be explored to influence students' various aspects of learning.

In one word, the interactive teaching mode based on educational games has the broader development space. It is believed that the interactive teaching mode based on educational games can offer a development direction with obvious feasibility for acupuncture major teaching.

\section{References}

[1] Chen, J.Q, Lin, W.R, Wang, S., et al. Acupuncture/electroacupuncture enhances antidepressant effect of seroxat: the symptom checklist-90 scores. Neural Regeneration Research, 2014, vol. 9(2), pp. 213-222. https://doi.org/10.4103/1673-5374.125353

[2] Auteroche, B., Gervais, G., Auteroche, M., et al. Acupuncture and Moxibustion. China Medical Abstracts, 2015, vol. 9(2), pp. 67-69.

[3] Kova,1 J.P., Young, G.S. Computer Training for Entrepreneurial Meteorologists. Bulletin of the American Meteorological Society, 2010, vol. 82(5), pp. 875-888.

[4] Marchiori, E.J., Torrente, J., Moreno-Ger, P., et al. A narrative metaphor to facilitate educational game authoring. Computers \& Education, 2012, vol. 58(1), pp. 590-599. 改后. https://doi.org/10.1016/j.compedu.2011.09.017

[5] Boyle, E.A., Macarthur, E.W., Connolly, T.M., et al. A narrative literature review of games, animations and simulations to teach research methods and statistics. Computers \& Education, 2014, vol. 74(3), pp. 1-14. https://doi.org/10.1016/j.compedu.2014.01.004 
[6] Tian, Y., Zhou, M., Xia, D., Li, F.D. Research and Design of Preschool Children's Educational Game Based on Mobile Augmented Reality.e-Education Research, 2019, vol. 40(4), pp. 68-75.

[7] Pu, S.L. How to Construct an Efficient Classroom of Primary Mathematics: Exploration on the Way of Integration of Educational Game and Primary Mathematics. Scholarly Weekly, 2019, vol. 11, pp. 74.

[8] Olasina, G. Exploring how users make sense of virtual worlds using the symbolic interaction theory. Journal of Gaming \& Virtual Worlds, 2014, vol. 6(3), pp. 297-311. https://doi. org/10.1386/jgvw.6.3.297 1

[9] Kang, Y., Cheng, X. Teacher Learning in the Workplace: A Study of the Relationship between a Novice EFL Teacher's Classroom Practices and Cognition Development. Language Teaching Research, 2014, vol. 18(2), pp. 169-186. https://doi.org/10.1177/13621688 $\underline{13505939}$

[10] Gu, W.Q. Input Adjustment and Interactive Adjustment in Foreign Language Classroom Teaching. Foreign Language World, 2010, vol. 40(3), pp. 66-70.

[11] Shang, W.B. Teaching Model of "Subjective Interaction" in College English from the Perspective of Inter-subjectivity. Foreign Language Research. 2013, vol. 42(15), pp. 141-143.

\section{$7 \quad$ Author}

Qiong Pan is an associate professor in the Yunnan Xinxing Occupations Institute, Qujing, China (panqiong_8866@163.com).

Article submitted 2019-06-05. Resubmitted 2019-07-15. Final acceptance 2019-07-21. Final version published as submitted by the authors. 